\title{
The Controversy over Intellectual Property in Nineteenth-century France: A Comparative Analysis between Proudhon and Walras Rémy Guichardaz
}

\author{
University of Strasbourg, CNRS \\ BETA UMR 7522 \\ F-67000 Strasbourg, France \\ rguichardaz@unistra.fr
}

\begin{abstract}
The debate over intellectual property in nineteenth-century France was structured as follows: liberal economists advocated a system of perpetual intellectual property rights, while socialist thinkers called for their total abolition. Between these two extremes, other economists supported a temporary form of intellectual property: in particular, Pierre-Joseph Proudhon and Léon Walras both converged towards this third solution. This article shows that they in fact provide two different analyses of intellectual property rights, which partly overlap with positions in current debates in innovation studies.
\end{abstract}

Key words: intellectual property, Walras (Léon), Proudhon (Pierre-Joseph), copyright Classification-JEL: B13, B14, B40 


\section{Introduction}

Intellectual property concerns the creation of immaterial goods for which a specific owner is legally entitled to a monopoly. This specific kind of property primarily comprises patents and copyright. Patents are granted for inventions, and have a limited duration (generally 20 years). Copyright protects an intellectual work, including literary works, and lasts for the life of the author plus 70 years.

Both of these kinds of intellectual rights have been considerably reinforced since the 1980s under the leadership of the United States, notably through the Agreement on Trade-Related Aspects of Intellectual Property Rights (TRIPS). Lawyers and economists have justified this legal strengthening by arguing that the commodification of knowledge would increase the level of innovation and hence benefit economic efficiency (Kitch, 1977). It is an understatement to say that this consensus has progressively vanished, giving way to a serious debate about the contemporary relevance of this system of intellectual property rights (Heller \& Eisenberg, 1998; Boldrin \& Lévine, 2005).

The debate now extends beyond economics and increasingly involves juridical, ethical, and philosophical considerations. Many scholars defend a utilitarian paradigm which justifies intellectual property rights as a legal means to encourage people to produce immaterial goods. From this perspective, intellectual property rights should be granted to inventors or authors only if this does in fact incentivize them to create. By contrast, the jus naturalist paradigm justifies intellectual property in terms of a moral obligation on society to reward inventors and authors for their labor. This traditional justification of intellectual property has been refreshed by a growing number of scholars as a means of defending the current state of the law (Merges, 2011, Mossoff, 2014). Some commentators have even considered perpetual intellectual property rights (Schulman, 1990; Galambos, 1999; Moore, 2001; Helprin, 2007).

However, it would be wrong to consider such discussions as the exclusive consequence of recent legal or technological changes, for very similar debates were ongoing in the nineteenth century, resulting in fierce debates between economists, lawyers, and philosophers, both in Europe and the United States. Although this debate is well known among historians and lawyers (Galvez-Behar, 2007, 2008, 2010; Rideau, 2010; Xifaras, 2010; Pfister, 1999), the case has attracted attention from only a few economists (Machlup \& Penrose, 1950, 
Lemennicier, 1995; Sagot-Duvauroux, 2004; Mangolte, 2010; Lallement, 2011; Poinsot, 2014).

In France, the question of intellectual property was controversial, particularly because the analytical tools employed by French economists of the nineteenth century were embedded with moral and ethical assumptions (Sigot, 2010). The polemic reached its climax at the Brussels Congress of 1858, which debated whether authors should have property rights at all. By the 1878 Congress of Paris, the idea of intellectual property had largely been accepted, and the dispute had shifted to the question of its duration. In both cases, what was at stake was not simply the question of whether creators had rights, but the very nature of this right and its legal implications.

- An initial radical position was endorsed by a faction of liberals who advocated perpetual intellectual property rights conceived as an extension of the landed property regime (Bastiat, 1862; Jobard, 1844: Molinari, 1852, 1855, 1856; Modeste, Paillottet and Passy, 1859). According to them, this alignment of intellectual property with the legal prerogatives of land property (i.e. being absolute and perpetual) was fair since it complied with a Lockean interpretation of natural law: any man who creates something thanks to his labor should be the owner of the output. In this perspective, intellectual property is linked to the fundamental rights of the person.

- On the other hand, socialists such as Louis Blanc (1839) rejected any form of ownership of immaterial goods on the grounds that such goods are naturally unlimited in quantity. Immaterial goods are cheap to reproduce and can be shared without being depleted. Consequently, the role of the State is to preserve free access, while funding creative activities through a "socialized book repository" (librairie sociale) in charge of evaluating artistic achievements.

Between these two extremes, other economists proposed intermediate solutions in which ownership was time limited. Here we consider proposals made by Pierre-Joseph Proudhon and Léon Walras, which draw our attention for several reasons. First, Proudhon and Walras share the idea that political economy must transcend a purely utilitarian approach, while also rejecting the rigorist natural law interpretation defended by French liberals. They thus promise to provide useful insights into the current academic discussion on intellectual property rights, insofar as their arguments avoid the traditional opposition between natural law and utilitarianism. 
Second, Proudhon's and Walras's writings on intellectual property encompass a wide range of the positions that have been expressed during the debates. In fact, as the years went by both of them changed their positions: starting out from the two extremes - Proudhon for abolition and Walras for the perpetual system - they finally converged on a system of timelimited ownership. Their shifting positions have not as yet been scrutinized in the academic literature, with the exception of Lallement (2011) who focuses on the changing position of Walras, and Sagot-Duvauroux (2004) contextualizing the second position of Proudhon. However, although these papers correctly point out the convergence of their positions over time, they do not account for the analytical differences between Proudhon and Walras on the topic of intellectual property.

A comparative perspective on the writings of Proudhon and Walras is therefore useful, not least because these analytical differences echo recent discussions in the sphere of the economics of innovation about the traditional knowledge tradeoffs introduced by Arrow (1962) in justifying intellectual property : no doubt, intellectual property temporarily disturbs the static efficiency of the economy because of its monopolistic structure, while increasing dynamic efficiency in incentivizing people to innovate. However, Proudhon's analysis suggests that this standard tradeoff is only one part of the picture and ignores the fundamentally dynamic features of knowledge production.

The aim of this article is to show that, despite their shared normative standpoint, Proudhon and Walras actually provide two different understandings of intellectual property. To that end, in the first section we reconstitute the various steps in Proudhon's and Walras's reasoning about intellectual property, and we clarify their final position in favor of a time-limited solution (1). We then show to what extent their positions are actually based on different analytical and normative arguments that can provide useful insights for the current economic debate (2).

\section{Proudhon's and Walras's positions on intellectual property rights: From opposition to}

\section{convergence}

Proudhon first addressed the issue of intellectual property rights in his controversial book Qu'est-ce que la propriété? (1840). He does not explicitly reject such a property regime, but 
provides economic arguments implying a central system of payment which would conflict with the property solution. The Proudhon's second position is expressed in a book entirely dedicated to the issue of intellectual property, in which he favors a temporary privilege system while remaining very critical about the concept of ownership of immaterial wealth (1.1). Walras's first position, meanwhile, was published in 1859 in the Journal des Economistes, and there he supports a system of perpetual intellectual property; whereas in an article for the Gazette de Lausanne of 1880, Walras's position has come to echo Proudhon's in supporting a time-limited system.

\subsection{Proudhon on intellectual property rights: From public property to temporary privilege}

1.1.1. Proudhon's position in Qu'est-ce que la propriété? (1840)

In Qu'est-ce que la propriété ? (1840) Proudhon's viewpoint is strongly egalitarian. According to him, wealth should be distributed equally among workers through a mutualist system in which workers are considered as associés. This strongly egalitarian statement must be understood in the light of Proudhon's economic theory and his famous denunciation of private property in the form of both capital and land. For Proudhon, wealth production is the outcome of a social cooperation between workers which exceeds the contribution of each worker taken separately. This social cooperation falls under the key concept of the "collective force" (force collective), where the collective force acts as an autonomous factor of production that is greater than the summation of the individual forces. Then the capitalist (or the landowner), by paying each worker separately and as if they were acting alone in undertaking the task, is able to privatize the great surplus emanating from the collective force:

A force of a thousand men acting for twenty days has been paid as if it were the force of one acting for fifty-five years; but this strength of thousand has produced in twenty days something that the force of one, repeating his effort over a million centuries, could not accomplish: is the market fair? Again, no. $\left(1840\right.$, p. 157) ${ }^{1}$

According to Proudhon, the "collective force" is not only the source of wealth, but is also a powerful source of equality among workers. For the collective force emerges only thanks to the complementariness of skills and talents, which, in turn, implies equality among the workers. Proudhon draws this conclusion from a very specific reading of Adam Smith (Béraud, 2009), acknowledging that nature has given men different levels of talent, but adding

\footnotetext{
${ }^{1}$ All translations are by the author of this article.
} 
that society, thanks to the division of labor, will restore equality by making them equal in their complementarity: the division of labor draws upon unequal human capabilities, which he calls "functions" (fonctions), but these functions find their raison d'être through commutative "relations" (rapports), that is to say through exchanges of goods and services that are mutually indispensable to each other.

Although the concept of patents or literary property is not mentioned specifically, in paragraph 7 of Chapter III Proudhon does apply his holistic analysis in terms of "collective force" to the producers of intangible goods. In this passage, Proudhon acknowledges that "All works to be performed are not equally easy: there are some that require great superiority of talent and intelligence and this superiority make the price" (1840, p. 224). However, he adds that "this physiological condition of genius adds nothing to his [the producer's] social rights" (1840, p. 173). Indeed, Proudhon even specifies that the producers of intellectual wealth are those who are the most accountable to the collective force, since their individual capabilities are always the result of the social context in which they belong:

If it is glorious to charm and instruct men, it is also honorable to feed them. When, therefore, the society, in accordance to the principle of the division of labor, assigns a mission of art or science to one of its members, by sparing this one of the common work, the society owes him compensation for the industrial goods that he can no longer produce, but no more than that. (1840, p. 177)

This quotation is a notable illustration of the Proudhonian idea of equal complementarity between workers: while the talent of a few grows, others have to be dedicated to the production of essential goods, meaning that the division of labor has to be pushed forward. Thus, the most talented people are just like any other workers, and like everyone else they receive from the collective force far more than they can give back. In other words, one's status as author does not give any special property claim to the work: the author is entitled to receive the value that he draws from his labor, but not entitled to exclude others from the work. The author's labor does not differ from any other type of labor, and should be rewarded according to the same egalitarian rule shared by the associés:

A poem that would cost its author thirty years of work and 10,000 $\mathrm{f}$ in travel expenses, books, etc., must be paid for by thirty years of regular worker salary, plus 10,000 $\mathrm{f}$ of compensation. Suppose that the total amount is 50,000 f; if the society which acquires the masterpiece numbers a million men, I personally owe 5 centimes. (1840, p. 172)

However, Proudhon does not explain how such a compensation scheme could be implemented or how equality would thereby be reached. This ambiguity remains in the 
second memorandum to Qu'est-ce que la Propriété? (1840), published in 1841 and entitled Lettre à AM. Blanqui sur la propriété. In this second essay, Proudhon mentions intellectual property rights in responding to the economist Wolowski (1840) who advocates a timelimited property. For Wolowski the length is justified by the fact that intellectual wealth is the result of past ideas owned by everyone. Accordingly, Wolowski explains, the expiration of the property could be considered as the starting point of a "collective right on production" which the society is entitled to claim. Proudhon points out that such dichotomy echoes his analysis of wealth origination in terms of collective force, and then asks ironically why Wolowski (1840) does not extend his normative result to other property rights: after all, the output from any productive task - material as well as immaterial - will always far exceed one's personal input. Yet Proudhon does not specify to what extent he agrees with Wolowski's proposal, and defers this matter to future work.

\subsubsection{The second position of Proudhon in Les Majorats Littéraires (1862):}

Proudhon expresses his final position on intellectual property rights in Majorats Littéraires (1862), a work entirely dedicated to this issue. This book emerged at a moment of high sensitivity. Thanks to the publication in 1859 of De la propriété intellectuelle, by the liberal economists Passy, Modeste, and Paillottet, the perpetual position had gained ground. Their intervention was followed two years later by a special commission created by Napoléon III and charged with reforming literary property law. Thus Proudhon's Majorats must be understood as a very fierce reaction aimed at stopping the commission. Yet in this text, instead of the perpetual intellectual property regime or his earlier rejection of any system whatsoever, Proudhon here advocates a "temporary privilege of selling” (1862, p. 5).

Proudhon's change in position on intellectual property rights can be explained on several grounds. First, it is likely that Proudhon himself realized that his egalitarian scheme sketched in Qu'est-ce que la Propriété? would be impossible without a central planner such as the State. As we will see in what follows, Proudhon was dissatisfied with such a solution for both economic as well as political reasons. By contrast, the great advantage of the privilege system is that it gives the public the choice over what products are worthy of being bought. Proudhon explains that artistic and inventive activities are risky and that their success depends on the tastes and the needs of people. Hence, the author has to be considered an 
entrepreneur of publicity, at his peril; his publications, from a commercial viewpoint, are uncertain; consequently there is between him and the society a tacit contract under which the author will be remunerated with fees, by a temporary privilege of selling. (1862, p. 49)

Proudhon's shift of position can also be seen as the result of the influence of the lawyer Charles-Augustin Renouard, one of the most influential and respected specialists on patent and literary property laws in France at this time. ${ }^{2}$ Although Proudhon does not refer to Renouard in the Majorats Littéraires (1862), he had discussed his work on patent law and trademarks in Système des Contradictions Economiques (1846), and it is likely that Proudhon knew of his Traité des droits d'auteur (1838-1839). This conjecture can be supported by considering the nature of Proudhon's own argument, which is close to Renouard's own legal reasoning. Proudhon's challenge was to distinguish the concept of the rights of authors and inventors from the concept of property, which in his mind referred to the absolute and perpetual ownership of land or capital. The words used by Proudhon parallel the ones used by Renouard in the first part of his Traite des droits d'auteur (1838), where he describes an author as a "worker" or an "artisan" (Ibid., p. 460) and says that society must pay for "the service that has been rendered" (Ibid., p. 472). In similar manner, Proudhon claims vehemently that the artist must be seen not as an owner of capital but as a "worker" who deserves a "salary", "compensation", or a "respectful subvention" in exchange for his “service" (1862, p. 129).

For Proudhon, such a distinction between owner/capital and worker/service is crucial, as it directly echoes his last position on the issue of property as expressed in his final work Théorie de la Propriété (1866): although private property is still unjust, a small system of ownership is needed in order to preserve individual freedom against the autocratic power of Napoléon III. In other words, the absolute character of private property must be now recognized as a balance against the absolutism of the State. But for Proudhon, such a political justification for private property has nothing to do with the false concept of property over intangible assets favored by his liberal opponents.

In order to demonstrate the weakness of the liberal position, Proudhon first recalls his reasoning of 1840: whereas laboring certainly does confer a right over the product produced,

\footnotetext{
${ }^{2}$ Renouard produced a substantial body of work on both patents and copyrights (droits d'auteur). His most famous books on these issues are Traité des droits d'auteur, dans la littérature, les sciences et les beaux-arts published in two volumes in 1838 and 1839, Traité des brevets d'invention on the patent system in 1844, and a broader legal work questioning the relationship between the concept of property and that related to patents and copyright entitled Du droit industriel dans son rapport avec les principe du droit civil sur les personnes et sur les choses (1860).
} 
it does not however imply any appropriation of the "fund" (fonds), that is to say the capital or the source from which it comes. ${ }^{3}$ Proudhon draws a parallel between artistic and inventive activities and industrial ones, seeing both as the result of the collective force: "we no more produce our ideas, in the strict sense of the term, any more than we produce body" (1862, p. 23). This statement is intentionally directed at a metaphor used by Pluquet, who draws parallels with the literary work, conceived of as a field in which the author labors and thereby becomes the owner in perpetuity. For Proudhon this comparison is nonsensical: the book is a product that the author can enjoy by exchanging it with another product. By contrast, the field or the "fund" (fonds) of the work are the ideas, concepts, and forms used by the author. These assets are the result of the collective force, past and present, and should remain therefore free for all to access.

Proudhon extends his earlier line of reasoning by arguing that the labor-based theory endorsed by French liberals to justify perpetual intellectual property is self-defeating. He points out that the appropriation of intangible things does not restrict individual freedom in the same way as other property rights do: while ownership of land limits actions only with respect to the surface of that land, intellectual property restricts an entire range of actions that is virtually unlimited in place and time. Indeed, intellectual property does not protect objects as such but rather their conceptual representation, so that it prevents others accessing any exemplar for any use, including improving them over time. Because of this specific implication for freedom, perpetual rights are a threat to the freedom to work and create, and also threaten the very notion of property itself. Proudhon takes the fictional example of a combination of perpetual patents over a plow. In such a situation, those who cannot pay the fees are no longer able to compete with those who own the technology. Eventually they would be forced to leave their lands, as they would not be allowed to reproduce the plow with their own labor:

We set out with equality, and thus does industrial property undermine landed property; work is impossible for the poor, the smallholder forced to abandon his land [...] In short, the community of the soil would be fatal for the freedom to work, to the independence of the spirit; meanwhile, in return, the appropriation of the intellectual domain would be disastrous to landed property.

\footnotetext{
${ }^{3}$ Proudhon takes the following example: "In spring, the poor women farmers go to the wood to pick some strawberries that they bring back to the city. These strawberries are their product, and consequently, to use Abbé Pluquet's language, their property. Does this prove that these women are so-called owners? If we say so, everybody would think that they are owners of the wood where the strawberries come from. Alas it is the contrary that is true" (1862, p. 29-30).
} 
Hence, someone who wants to respect the natural law account of land property has no choice but to reject intellectual property. Accordingly, Proudhon claims that a book or an invention can only rightfully be owned as a product. This implies a sui generis system of privilege, different from the concept of property. Such a privilege is necessarily time-limited since it protects the intellectual work not as capital but as a product. Being products, books or inventions cannot be exchanged several times for the same "service", otherwise it would be "as if the producer of wheat, meat, wine, etc., declining payment for his goods, wanted to substitute the price with a perpetual annuity" (1862, p.51). Certainly, such a conceptual confusion between product and "fund" (fonds) would lead to a serious violation of the commutative justice principles defended by Proudhon.

\subsection{Walras on intellectual property rights: From perpetual property to} temporary property

1.2.1. Walras's first position in De la propriété intellectuelle. Position de la question économique (1859) :

Walras sets out his initial position on the question of intellectual property in a comment on the 1859 book by Passy, Modeste, and Paillottet, published in Journal des Economistes (1859). Here Walras concurs with the conclusions of the authors, yet on the basis of different economic reasoning which he sketches in two steps: Walras aims first to determine the nature of intellectual wealth, and then applies his theory of property accordingly. Regarding the first step, Walras closely follows the conceptual framework of his father, who distinguished "social wealth" that is both useful and limited in quantity, from "natural wealth" that is not scarce. Only "social wealth" can be the object of study by political economy, because its scarcity gives things an exchange value translated into a market price. The main problem for Walras is therefore to examine whether intellectual goods can be considered as "social wealth".

For that purpose Walras, draws a distinction, echoing the one used by Proudhon in Majorats (1862), between ideas and intellectual wealth itself. Ideas are part of the natural wealth as they cannot be divided into distinguishable and useful things. By contrast, Walras claims, intellectual wealth is precisely that which has an exchange value. Walras's reasoning on this point is mainly empirical: the fact that there is a market price for books, concerts, shows etc. tends to show that intellectual wealth is somehow scarce and is appropriated by 
people. Walras observes that this wealth is a form of capital, as it remains intact after the first use:

From valuable, appropriable and exchangeable intellectual capital, there issues on a daily basis valuable, appropriable and consumable revenues. These are: the pleasure for each spectator in contemplating the work of an artist, the interest that each reader finds in browsing through a book by a writer, the emotion that every auditor feels in listening to the opus of a musician, etc. $(1859$, p. 401$)$

After identifying intellectual wealth as "social wealth", Walras details the moral foundations of intellectual property rights. On this point Walras draws upon the same Lockean source of inspiration as most of the French liberals of his time: creators should be the perpetual owners of their work (embodied as capital) and their revenues (embodied as the sale price of the work), since they are the owners of their bodies and their capabilities. Thus, Walras concludes, "the intellectual producer is naturally the owner of the fruit of his work; consequently, he is the owner of the sale price of the intellectual incomes" (1859, p. 403). Contrary to Proudhon, Walras does not perceive it as unfair that capabilities can be the arbitrary result of the social context, since they are still the legitimate property of the individual. ${ }^{4}$

As a final remark, Walras stresses that his economic reasoning provides stronger foundations for perpetual intellectual property rights than the argument, proposed by Passy, Modeste, and Paillottet (1859), that land property can be considered in a manner parallel with intellectual property. Walras rejects such an analogy. He considers that land property cannot be justified by the labor theory of appropriation: "I cannot possibly accept that labor creates a field where before there was only a surface, and that the fruit of the agrarian labor is the entire value of the ground. [...] This a different right from the right of labor, this is the right of the first occupant" (1859, p. 399). Conversely, intellectual property can be fully justified by reference to the efforts and labor of the creators. Once again, Walras is influenced by his father, who rejected land property on the basis that such an asset is a form of natural wealth which does not result from anybody's labor.

\footnotetext{
${ }^{4}$ According to Walras, distributive justice is that which "presides over the competition and that is represented with a crown in hand; it is the one that requires that the runners be rewarded for their agility, that is to say, in the order in which they reached the goal" (1986, p. 139). The unequal distribution of talents is actually one of the main justifications for distributive justice: "As they freely perform their destiny in a more or less successful way, or more or less meritorious, it appears that men have differences of abilities, talent, application, perseverance, success which make them unequal; and this inequality is the fact on which distributive justice is based" (1860, p. 44). This absolute respect for self-ownership leads some commentators to describe Walras as a precursor of leftlibertarianism (Gharbi \& Sekerler Richiardi, 2010).
} 


\subsubsection{Walras's second position in De la propriété intellectuelle (1880)}

In 1880, Walras revised his initial position in favor of a view of intellectual property rights as temporary. Lallement (2011) contends that this second position was the outcome of reasoning that was already latent in 1859. Based on an analysis of the correspondence between Walras and his father, Lallement conjectures that the article of 1859 was a strategy adopted by the young Walras in order to become accepted within the very tight circle of French economists. In 1880, and now a professor at the University of Lausanne, his personal situation had changed sufficiently that he could reveal his true opinion. ${ }^{5}$ Lallement also stresses the likely influence of the works of Renouard and Jules Dupuit (1861) in explaining this change. ${ }^{6}$

In this second article Walras reconsiders the connection between intellectual wealth and social wealth. He explains that the equivalence between the two cannot hold, since "it is the nature of immaterial things to be shared without diminishing, to spread by multiplying" (1880a, p. 1). In other words, Walras clearly conceptualizes intellectual wealth as a "public good". However, while artistic ideas and inventions cannot be considered as social wealth, they can meet many social needs both useful and limited in quantity. From this perspective, intellectual property must be treated not as "a special case of the general theory of property" (1880a, p.1) but as a sui generis device tailored for meeting the collective interest. This can only be achieved with a time-limited system. Indeed, on one hand Walras assumes that without intellectual property "The continuation of industrial inventions, the composition of artistic work and literature would be strictly abandoned or, at least considerably neglected" (1880b, p. 1); yet, on the other, intellectual property may generate economic inefficiency by restricting the access to intellectual goods, since "instead of having them freely, we are obliged to pay at the maximum profitable price" $(1880$, p. 1). Temporary rights, then, allow society to benefit from the first effect while minimizing the drawbacks of the second.

\footnotetext{
${ }^{5}$ A further argument offered by Lallement (2011) in favor this hypothesis is the fact that Walras, at the end of his 1859 article, suggests that the State could expropriate the author on the basis of "public utility". Such a proposition would tend to prove that Walras was not convinced by the system of perpetual rights. However, this kind of legal remedy for intellectual property was, at this time, broadly supported by other scholars and economists who were in favor of perpetual rights, such as Joseph Garnier (1873). Moreover, the French Code Civil of that time already provided limits to the general regime of private property with an expropriation procedure for "public utility". Thus the suggestion made by Walras appears to be rather banal, and fully compatible with the perpetual position.

${ }^{6}$ Walras produced a note in his Cours d'économie sociale with several references concerning intellectual property, including the work of Renouard (Lallement, 2011).
} 
One might think that Walras here adopts the utilitarian rationale for intellectual property, such as was supported by Dupuit (1861). Nevertheless, Walras does not limit his demonstration to purely economic considerations. Rather, his article aims to demonstrate that temporary rights comply, above all, with principles of justice. In continuity with his first article, Walras claims that justice consists in giving people the full economic value of their labor. However, in that case, one could ask why creators are entitled to get only temporary rights while the producers of tangible goods are endowed with perpetual rights? On that point, Walras's answer is close to Proudhon's, stressing that people create intellectual wealth thanks to past ideas and the general heritage of society. Consequently, temporary rights are the only ones compatible with distributive justice, which requires that everyone be rewarded according to their actual contribution.

\section{Proudhon's and Walras' positions on intellectual property: A comparative approach}

Having clarified the respective positions of Proudhon and Walras, and how they converge on the thesis of time-limited rights, we demonstrate in the next section how in fact the two authors differ in the way they justify and conceptualize those rights. This difference not only impacts upon the legal nature and philosophical foundations of intellectual property, but also has analytical consequences leading to different normative outcomes. In order to highlight this difference, we proceed to a comparison of the argumentation employed by Proudhon and Walras through examining three main "knowledge dilemmas" related to the intellectual property system. The first knowledge dilemma identified by Proudhon and Walras has echoes with the traditional economic analysis of intellectual property initiated by Arrow (1962) (2.1). The second knowledge dilemma stresses the dynamic properties of knowledge production: we show that this second dilemma lies behind the Proudhonian boundaries of intellectual property as expressed through his concept of collective force, while Walras remains within the traditional Lockean paradigm by aiming to reconcile individual labor with property-based reward (2.2). As a result, we discuss to what extent the Proudhonian approach should attract our attention by suggesting a third mode of regulation of intellectual property, which is not endorsed exclusively by either the State or the market (2.3).

2.1. The first knowledge trade off: Knowledge as a public good 
Considered analytically, the convergence of Proudhon and Walras on a time-limited solution is due first to a conventional analysis of knowledge production on which there is a tradeoff between static efficiency and dynamic efficiency (Arrow, 1962). This first tradeoff is particularly salient in the Walrasian argumentation from 1880, which operates a standard cost-benefit analysis between the benefit of property-based incentives and the economic costs of monopoly pricing (cf.1.2.2). This Walrasian understanding of the processes of innovation relies on a standard economic view according to which inventors and artists are essentially driven by extrinsic motives. From such a perspective, the higher the property-based incentive, the higher the amount of intellectual wealth that will be produced by authors and inventors.

Proudhon acknowledges that pecuniary incentives matter, but remains very reluctant to use that point as a central argument in defense of his privilege system. Proudhon's hesitancy regarding the incentive virtues of intellectual property rights is due to his specific conception of the creative process: inventors and artists are not only interested in money, but are motived foremost by intrinsic motives such as "Truth" and "Beauty" (1862, p. 143). Proudhon contends that strong or perpetual property rights could have a "crowding-out effect" which would alter those intrinsic motives. In other words, Proudhon contends that intellectual property rights are not neutral as regards the creative process of inventors and artists, and that in fact they orientate their talents and efforts toward commercial and short-run returns rather than true artistic value.

This point receives an eloquent treatment in the second and third parts of the Majorats, entitled "Considérations Morales et Esthétiques" and "Conséquences Sociales", where Proudhon expresses great concern about the use of pecuniary incentives for encouraging the production of works of art. Strong or perpetual intellectual property rights would feed the greed of artists, inclining them to produce futile goods, whereas their true role is precisely to further the emancipation of people. Likewise, artistic works would be substantially and formally shaped by economic requirements, decreasing the aesthetic value of the goods themselves and harming the enlightenment of the public. ${ }^{7}$ Interestingly, Walras also observes

\footnotetext{
${ }^{7}$ In Du principe de l'art et de sa destination sociale (1865) Proudhon considered that artists have a key role to play in transforming society. His reflections are reminiscent of Schiller's aesthetic utopia, which conceives art as a means of perfectibility for the human against the backdrop of a society devoted to utilitarianism and economic rationality. In Mes Haines: causeries littéraires et artistiques (1866), Zola would reproach him for this political and moralizing conception of art. The Proudhonian analysis describes a continual tension between the chrematistic aspect of capitalism and ascetic values. In this sense Proudhon anticipates the criticism formulated by Adorno and Horkheimer (1944) about the "cultural industries" as a new form of capitalistic alienation extended to the sphere of cultural production.
} 
that the majority of literary works have a "lesser artistic value but a greater market value" (1880b, p. 1). But Walras takes this market misalignment as a typical feature "from which the property can be recognized as the artistic property of the artist" (1880b, p. 1).

As a result, Walras proposes that the scope of intellectual property rights is first a matter of incentives, whereas Proudhon expresses the exact opposite stance, claiming that there is a point beyond which a marginal increase in the level of incentives will lessen the quality of artistic or scientific goods thereby produced. In Proudhon's view, the search for Truth and Beauty should not in any way be connected with the actual economic value of the goods which thereby emerge.

\subsection{The second knowledge tradeoff : Knowledge as a cumulative production process}

The second knowledge tradeoff identified by Proudhon and Walras is based upon the idea that knowledge production is driven by a fundamentally cumulative process, which is to say that future knowledge production depends on a diachronic relationship with knowledge from the past (Scotchmer, 2004; Antonelli, 2007). Walras raises this point indirectly in 1880 where he stresses the twofold origination of intellectual work; however, he uses that point only as part of an argument based on considerations of justice in order to justify the temporary nature of intellectual property: distributive justice requires adjusting the length of intellectual property rights in accordance with one's merit. By contrast, for Proudhon the temporary aspect of intellectual property stems from the very nature of immaterial wealth. This Proudhonian understanding can be identified in his surprising description of artistic goods and inventions. For whereas Walras considers that books and inventions can be considered as capital as they do not disappear after their first use, Proudhon repeatedly insists that these goods cannot in any sense be assimilated to a form of capital, and in fact are products: "the work exchanged is never anything except a product, a fungible thing, consumable, the contrary to what we name, by a generally accepted use, property, that is to say a fund" (Proudhon, 1862, p. 37).

Though it may at first sight seem rather confusing, we contend that the Proudhonian description of intellectual wealth is better understood through his collective force analysis of 1840. As we have seen, the collective force is that which enables individuals to produce more than the sum of their individual efforts, thanks to the complementarities between them. Now, the problem with intellectual property is that it artificially turns intangible assets into 
"capital", thereby removing the asset from the sphere of the collective force, which in turn hinders its consumption by others in producing further goods:

the duration of literary works, instead of running its normal course, would be artificially and indefinitely extended by the very action of the privilege, so that it would consequently be an obstacle to the production of new works at the great expense of progress. $(1862$, p. 54)

Thus, the value of material goods is pecuniary and quantitative as it increases with scarcity, whereas the value of intangible goods is mainly social and qualitative, as the more people have access to one generation of intangible goods, the more they breed further improvements shortening the life cycle of this generation. Literary property, on the one hand, prevents the necessary updating of expressions, forms, and tastes: "Everything is immobilized by appropriating. Do you understand now how writings which, by themselves, would have not lasted ten years will be imposing for centuries?" (1862, p. 209). Industrial property rights, on the other hand, may deter technical developments: "The series of improvements or inventions progresses in the manner of a line of reasoning: So would you prevent the individual from using his reason?" (1862, p. 236). Put differently, the idea of intellectual property fails to consider the collective dynamics of knowledge production, since its exclusionary nature simultaneously encompasses knowledge as an output (the owned-product) and as an input (the means of production).

In Proudhon's view, these features of the knowledge dynamic prove that authors and inventors should be considered as workers. And like any other workers, they produce social assets which are depleted over time, albeit in the particular sense that these goods need to be reshaped and improved by others. Once disclosed to the public, the work irreversibly impacts upon the opportunities and the imagination of the collective force; it is no longer possible for others to act as if the work had not existed. The fair remittance for the creator's labor is then strictly bounded by the rights of others to make productive use of that knowledge through their own labor. This boundary is given by the "consumable" nature - meaning precisely the social features - of the intellectual product, and guarantees the fairness of the exchange between creators and the society.

This account differs from that given by Walras, who justifies time-limited rights as a requirement of distributive justice, raising questions about "to what extent the scientific, artistic, industrial ideas really belong to authors and inventors and to what extent we owe 
these ideas to them, and only to them" (1880c, p. 1). ${ }^{8}$ Proudhon's framework, by contrast, invites us to tailor the length of the intellectual property rights according to product characteristics (i.e. its obsolescence), lies in the dynamic relationship between creators and the collective force of the society: perpetual or long property rights conflict with the productbased nature of the work as they would artificially extend its life cycle and so distort commutative justice.

This Proudhonian standpoint is even more salient as regards the type of intellectual products he identifies in the Majorats as partly "non-marketable" (non vénal). What he means by this point echoes the idea of the knowledge spillovers that Proudhon thought should be enjoyed by everyone. The argument is voiced as a moral demand: some artistic and scientific goods are necessary for any worthwhile individual and collective life project, and as such cannot be appropriated by anyone. Accordingly, externalities related to these goods must not be economically captured by their creators (they must remain "non-marketable"). This is why Proudhon explains that the aim of his privilege system is neither to reward creators ex post by according them the full value of their product (which is essentially incommensurable), nor to incentivize them ex ante, but rather to ensure that they can make a living:

the magistrate, the savant, the artist, in producing non-venal things, are constrained to sustain themselves by consuming venal utilities, and many of them are penniless, it is just that the community pays them and covers their needs. [...] here it is not the product that is sold or bought; it is the man that is rescued, indemnified. For that purpose, the law grants to any author a temporary privilege, by letting him be judge of his need and of the necessity in which he has to trade. (1862, pp. 142-143).

Hence Proudhon, unlike Walras, rejects that a public scholar should make a profit from his writings. Once again, since intellectual wealth must be treated as a product, it would be contrary to commutative justice that society should pay twice for the same content. In the same way, Proudhon considers that "Any author who can live from his heritage who takes a penny from his writings, is in principle guilty of unworthiness" (1862, p. 137). Though this statement sounds more like a moral appeal than a legal requirement, it demonstrates how far

\footnotetext{
${ }^{8}$ It is on the basis of this proportional relationship between labor and appropriation that Walras explains why rights to literary works have a longer length compared to patents, since "we owe much more to artists and men of letters for their artistic and literary ideas than we owe to scholars and engineers for their scientific and industrial ideas" (Walras, 1880b, p. 1). As a result, Walras considers intellectual property as an ex ante incentive as much as an ex post reward, which effects an elegant reconciliation between collective interest and distributive justice, under which artists and inventors appropriate the full value of their talent.
} 
Proudhon's proposal is from a rigorist Lockean labor-based justification of intellectual property.

A second normative consequence can be drawn from the Proudhonian analysis in terms of moral rights. In countries governed by a system of civil law, moral rights are extrapatrimonial rights which aim to protect the work of the author. In the current French system these rights are perpetual and inalienable, meaning that they remain with the author and his heirs even if the work is sold to a third party, for example an editor. ${ }^{9}$ Lallement (2011) shows that these rights meet the Walrasian view on literary property even though he does not explicitly mention them. On the contrary, from a Proudhonian standpoint, such "moral control" cannot be justified per se. These rights are limited for the very same reason as those mentioned above. As producer, the artist cannot claim perpetual moral rights since, once disclosed, his work evolves independently of his will, forming part of the collective force that reshapes this output as a new input directed at meeting future needs and purposes. ${ }^{10}$ Likewise, Proudhon rejects the right to withdraw a work from the public sphere, as the disclosure of a product irreversibly transforms the author's initial ownership over the manuscript into public ownership of the content. ${ }^{11}$

\subsection{The third knowledge tradeoff: Knowledge as a collective entity}

The production of intellectual wealth depends not only on diachronic interactions from one generation of knowledge to another, but may also depend critically on the synchronic diffusion of current knowledge between individuals. The quality and the diversity of forthcoming ideas, works of arts, and inventions is determined by the quality of the process of sharing of idiosyncratic knowledge that is dispersed among agents endowed with heterogeneous but complementary skills. Some kinds of knowledge are indeed more crucial than others, as they play a role as an upstream input in the production of many further goods.

\footnotetext{
${ }^{9}$ In particular the right to the integrity of the work allows the author to object to any form of alteration of his work by others, even if this change is substantial and claimed publically by the "second author".

${ }^{10}$ Proudhon depicts this dynamic author-public interaction by taking the extreme case of scientific textbook: "For the same idea, the same truth, for the same law, there is a need for each generation, what did I say? for each category of students, a particular formulation; this means, in other words, that after ten, fifteen or twenty years, the work of the writer is perfectly consumed" (Proudhon, 1862, p. 72).

${ }^{11}$ For Proudhon such irreversibility results from commutative principles: "This is on the contrary because the public is irrevocably involved and made possessor thanks to the publication, and it is because there has been an exchange that the author and his family lose the faculty to sovereignly dispose of the book, and in compensation it is allocated a temporary privilege of selling" $(1862$, p. 65). It is worth noting that Proudhon was not the only one to support such a position: for example, his statement echoes one made by Victor Hugo: "as soon as the work is published the author is no longer the master of it. This is hence a new character that seizes it. It is this character who says: I am here, I take this work, I do what I think I am supposed to do with her, I, human spirit; I own her, she is mine now" (Hugo, 1885, p. 93).
} 
However, the commodification of intellectual property may diminish the positive externalities arising from the indivisibility of knowledge. While neither Walras nor Proudhon explicitly mention this point, we contend that an analysis of their respective accounts of intellectual property policy could provide promising insights on this issue.

Walras assigns the State an extensive role in the regulation of intellectual property. For example, "in the case where the State would see an advantage to putting the invention in the public domain without further delay, it could buy the patent by compensating the inventor" (1880b, p. 1). In the same way, Walras contends that "monuments, some statues, some tables [...] that everybody can enjoy and be inspired by" $(1880 \mathrm{~b}, \mathrm{p} .1)$ should be funded by the State and considered as a public service. ${ }^{12}$ In 1897 Walras pushes his reasoning a step forward in suggesting that the State could act as a "unique entrepreneur" for the entire economy. From this perspective, the three knowledge tradeoffs would vanish entirely: intellectual property rights are replaced by a kind of centralized ex ante funding system of arts and innovation, the indivisibility of intellectual wealth is fully restored, and production reorganized as a public service.

This Walrasian viewpoint contrasts with the skepticism expressed by Proudhon about State regulation of intellectual property rights. In our view, this can be explained by Proudhon's dynamic vision of the economy, for he conceives of the creative process as an endogenous process framed by the socio-economic features of civil society, in which the State acts only as a disturbing force. For example, Proudhon thinks that the use of the expropriation procedure would create artistic and political conformism: mediocre authors would be encouraged to extol the merits of the Prince in return for compensation, while subversive ones would be censored. Likewise, in the industrial field, Proudhon contends that State funding would alter the entrepreneurial process, as entrepreneurs would no longer assume the risk associated with their economic choices.

This Proudhonian "evolutionist" account can be traced back to his Système des Contradictions Economiques (1846), where it functions as a riposte to a proposal by Louis

\footnotetext{
12 This corresponds to his definition of moral monopolies, which goes beyond the conventional opposition between public and private goods: of course, monuments or statues are not consumed by all in equal quantities, but the externalities that they produce might be considered as consumed by everyone in the same way. Following Béraud (2012), we might illustrate that point by a comparison between Mill and Walras regarding education: Mill explains that parents are unaware of the benefits that their children could enjoy from such a service, and this is why the State has to provide minimum education for all. Walras excludes this role of parental error, underlining that the individual is not concerned with public goods. He argues that it is important first for the State, not for the individual, that children receive the education that will enable them to pursue their own goals.
} 
Blanc in favor of a central system of awards for authors and inventors. Indeed, assuming that the State could act as a central planner by selecting innovative projects it is like assuming that

society knows in advance precisely what we should discover. Submitting entrepreneur projects for a preliminary examination is like prohibiting a priori any "movement". Because, once-again, relative to the goal that he is pursing, there is a step in which every industrial man embodies in his person the society itself, seeing better and further than all the other men together, and this occurs often without being able to understand himself or be understood. (1846, pp. 243-244)

Then there is no room for the State to imitate or even foresee this ongoing process. This justification contrasts with that offered by Walras, who portrays entrepreneurs as simple coordinators of different inputs of production, who do not take any risks, ${ }^{13}$ leading him to countenance a situation in which the State could act as a "unique entrepreneur". Of course, Walras is aware that such a situation could hinder sectorial progress,${ }^{14}$ but he does not include this limitation into his economic analysis.

Though Proudhon provides no explicit advice on alternative ways of managing intellectual property, we contend that his diagnosis and his conceptual framework of wealth production as resulting from both individuals and the collective force could offer promising suggestions. As explained above (cf. 1.1.1), Proudhon considers the collective force to be an autonomous factor in wealth creation which drives economic progress: by working together, workers create much more value collectively than they would if they remained isolated. The central question, then, is where this surplus actually comes from? In the light of the Proudhonian dynamic account of knowledge production, we contend that this surplus is the result of innovation, especially organizational innovation: by working together, men unconsciously create a cognitive framework through which they share and improve their ideas, their abilities, and their practices, so that their collective force exceeds the sum of their individual energies.

The analysis of this cognitive transformation is latent in Proudhon's early work, especially in his critique of Smith in Qu'est-ce que la Propriété? (1840). Proudhon accuses Smith of having reversed the causality of the economic progression from association to division. The

\footnotetext{
${ }^{13}$ Contrary to Walras, Proudhon conceives of entrepreneurial activity is intrinsically innovative and risky. This is why State intervention is undesirable from the point of view of society as well as from the point of view of the entrepreneur: "If it were possible to divide into two parts all the products of human reason, and to put on one side all the useful works, and on the other side all that has been expended in terms of force, mind, capital and time for error, we will see with dread that the amount of this account compared to the former is perhaps one billon percent. What would become of society if it should buy out all this liability and cover all those bankruptcies? What in turn would become of the responsibility and the dignity of the worker, if, covered by a social guarantee, he could, without risk to himself, unleash all the caprices of a delirious imagination..." (1846, p. 292).

${ }_{14}$ Walras proposes conducting a "great experiment" in order to decide to what extent competition between entrepreneurs should be preferred to a centralized direction.
} 
division of labor, Proudhon claims, must be seen as consequent to a prior association, because workers must have first cooperated in coming to use the talent of everyone in the best way possible. This coordination is embodied in collective rules and social norms, so that cognitively all the members act together as one. In other words, Proudhon underscores that growth and progress are ontologically different from how they are posited under the atomistic view of liberal economists. This latter point suggests that knowledge production is not a tradeoff between access and incentive as much as a tradeoff between individual and collective creativity - as "once again, it is not the individual who is creating: it is human industry" (1862, p. 236). Works of arts and inventions are less the result of the demiurgic expression of the creator's will than an individual manifestation of a broader collective process.

This holistic insight is particularly striking in Théorie de la Propriété (1866), where Proudhon describes how a mutualist system can compensate for the intrinsic drawbacks of intellectual property. By gathering together their skills and efforts, workers' associations preserve personal creativity while at the same time disseminating knowledge and best practices. They are not intended to

replace the individual initiative by the shareholder's action, as one could have foolishly thought in 1848 , but to ensure for all entrepreneurs of small and middle-size industry, as well as for small landowners, the benefit of discoveries, machines, improvements and procedures usually inaccessible to companies and poor fortunes. (1866, p. 122).

This pioneer form of patent pool aims to balance the necessity to release the genuine talent of inventors with the moral obligation to share their creative output with every shareholder, so as to benefit from further improvements: every producer, knowing that others are engaged by the same reciprocal obligations, is inclined to contribute to the commons and thus to keep improving.

At the end of his life, Proudhon tried to extend this holistic framework to every aspect of social life, including politics. Proudhon was particularly fascinated by the ability of civil society to organize itself outside the realm of the State. On that point, Proudhon's true originality was to stress that this spontaneous order does not always rely on market mechanisms to flourish: the market is only one procedure among many others for coordination between workers. Organizational diversity is managed by what Proudhon calls the "public reason" or "collective reason" (Proudhon, 1858), such that workers can express a plurality of opinions and publicly deliberate within their organizations, allowing them to transcend their individualistic standpoints (Chambost, 2004; Jourdain, 2017). This theoretical 
framework leads Proudhon to consider the social norms, habits, and traditions that workers appeal to in managing economic and social issues. ${ }^{15}$ In his view, such an empirical analysis is the primary ground on which any economic and social science should be built: "it was the responsibility of our century, the positive and precise genius of modern societies, to study the social instinct in its practical development, and to follow it in its speculative, moral and industrial manifestations" (Proudhon, 2010, pp. 143-144).

This socio-economic standpoint has two very important dimensions in the thought of Proudhon:

- First, workers' organizations cannot be based exclusively on one paradigm, since the modalities through which the collective force flourishes may depend on many factors: the number of men, the quality of their social relations, the nature of their industrial activity, etc. For example, peasants do not have to rely on an associative principle since they mainly produce their output on their own. In this case, the collective force is driven by exchange and competition rather than by formal collaboration. Meanwhile, association seems to be more appropriate for workers. Of course, this dichotomy might be challenged by innovations. As mentioned above, Proudhon discusses the great advantages that peasants could enjoy from cooperative organizations in terms of technological improvement. There is hence a range of intermediate solutions between private ownership and collective ownership.

- Secondly, procedures, rules, and contracts structuring the associations are always embedded within moral and norms that exceed the homo economicus model. By directing their efforts and skills towards a common goal, workers are able to form a community of peers and to sustain a shared vision of what is good and fair. These are embodied in cognitive frames and values that are ontologically distinct from individuals.

This framework echoes recent work by Ostrom (2007) challenging the Samuelsonian classification of economic goods: the commons are not defined by their immanent properties (namely rivalry and non-excludability) but by the way resources are regulated (Harribey, 2011; Allaire, 2013; Coriat, 2015; Broca \& Coriat, 2015). Notably, on Ostrom's view the commons are characterized by three criteria which match Proudhon's view (Ostrom, 1990).

\footnotetext{
${ }^{15}$ Economists, lawyers, and historians have shown how much the era of industrialization has also been a period of experimentation for a "hybrid" economic system (Polanyi, 1944; Leroy, 1913; Mauss, 1924). According to Proudhon, these experiences provide the empirical evidence that the collective force, in all its plurality, is the foundational source of economic dynamics (Laval, 2016).
} 
First, they are collectively managed by formal and informal rules embodied in social interactions. A commons implies the existence of a community of people agreeing to follow specific sharing procedures. Secondly, commons management implies supporting a collective vision about what the goal of the organization is. Individuals are cognitively framed and motivated by the community of peers, so that their ability to create and sustain the common resources is enhanced and strategic behaviors are deterred. Last but not least, the commons can be sustained through hybrid mechanisms that might differ according to the use of the resources, the goal and the status of shareholders, etc.

Recent examples issuing from the Internet, such as the Creative Commons initiated by Lessig (2004), can be seen as extending the Proudhonian logic of collective force: they are characterized by a mutualist logic through which people are engaged in improving knowledge resources, provided that they also freely share their own contributions. The logic of the commons and Proudhon's conception of the collective force share the same "third way" of resource regulation apart from private and State property: organizations and collective entities do matter, they have their own logic (public reason) and their own dynamics (collective force), to the extent that their rules and norms are not enforced by the State, but emerge through interactions and exchanges between peers who seek to balance individual genius with collective creativity.

\section{Conclusion}

Given the past as well as the recent debates on the justification of intellectual property rights, the writings of Proudhon and Walras remain of great interest in that they propose a balanced position which benefits creators in a way that exceeds the strict utilitarian incentivebased argument. Likewise, both Proudhon and Walras are plainly dissatisfied with a simple translation of the natural law rationale for property into the immaterial world. Accordingly, the systems they propose are sui generis.

From an analytical perspective, the theoretical clarity with which Walras distinguishes intellectual wealth from social wealth appears central to understanding why the appropriation of such goods is so costly in terms of static efficiency. Symmetrically, in depicting intellectual wealth as social products that fade over time under the action of the collective force, Proudhon helps us to grasp the cumulative and collective features of knowledge production: intellectual assets are bounded assets, in the particular sense that restrictions on accessing 
them are costly not only for the demand side (monopoly deadweight loss) but for the supply side as well. As we have seen, the appeal to the concept of collective force underlines that knowledge dynamics and the creative process is less about incentives than a matter of trust, networks, and social cohesion.

Our comparative approach has revealed important theoretical insights that may well prove useful in designing a future system of intellectual property. In this regard, it is worth noting that the Proudhonian view of the creator as an intellectual worker entitled to a "privilege", rather than as an intellectual owner of a "property", inspired legislative proposals by the French minister Jean Zay in 1936 (Sapiro, 2014) which rebalanced the interests of holders with the interests of the public. ${ }^{16}$ Likewise, the Proudhonian conceptualization of immaterial wealth as a product depleting over time sheds new light on contemporary reform proposals made by legal academics who advocate a rebalance between the public and the holders that evolves over time (Liu, 2002; Hughes, 2003): the older the work, the greater the rights of the collective force to access it and put it to use in producing further works.

\section{Bibliography}

Adorno, T., Hoekheimer M. (1944), La dialectique de la Raison : Fragments philosophiques, Gallimard, 2007.

Allaire, G. (2013), "Les communs comme infrastructure institutionnelle de l'économie marchande." Revue de la régulation. Capitalisme, institutions, pouvoirs, no. 14.

Antonelli, C. (2007), “Technological knowledge as an essential facility", Journal of Evolutionary Economics, 17(4), 451-471.

Arrow, K. (1962), "Economic Welfare and the Allocation of Resources for Inventions," In The Rate and Direction of Inventive Activity, ed. R. Nelson, Princeton, N.J.: Princeton University Press.

Bastiat, F. (1862), «Discours au cercle de la librairie» (16 décembre 1847), Euvres complètes, tome 2, Paris, Editions Guillaumin.

Béraud, A. (2009), «Proudhon et Smith », International Workshop The critique to political economy in 19th century. Part II: Pierre Joseph Proudhon, Universita degli studi di Verona, 16-19 Sep 2009.

\footnotetext{
${ }^{16}$ For example, this project advocated a balance between the interests of the public and the interests of the author by setting the right of exploitation to ten years after his death (with a non-automatic right of inheritance), and by fixing the proportional remuneration and collective agreements between producers and creators.
} 
Béraud, A. (2012), Walras et la notion de bien d'intérêt public, 8th Conference International Walras Association, Sep 2012, Toulouse, France.

Blanc, L. (1839), "Travail littéraire", Organisation du travail, livre III, Au Bureau du Nouveau Monde, 9e éd. 1850.

Boldrin, M. Levine. D. K. (2002), Against Intellectual Monopoly, online version.

Broca, S. Coriat, B. (2015) "Le Logiciel Libre et Les Communs.," https://hal.archivesouvertes.fr/hal-01174746.

Chambost, S. (2004), Proudhon et la norme, Presses Universitaires de Rennes, 295 p.

Coriat, B. (dir.) (2015), Le retour des communs, La crise de l'idéologie propriétaire, Les Liens qui Libèrent.

Dupuit, J. (1861), «Du principe de propriété. Le juste - l'utile » Journal des Économistes, 30 (1 et 2).

Galambos, A. J. (1999), Sic Itur Ad Astra: The theory of volition (Vol. 1), Universal Scientific Publications Company.

Galvez-Behar, G. (2007), « La propriété industrielle est-elle une propriété ? Le débat sur la loi relative aux brevets d'invention à la Chambre des pairs (1843), Entreprises et Histoire, Eska, pp. 108-110.

Galvez-Behar, G. (2008), «Si loin, si proches. Inventeurs et artistes au regard de la propriété intellectuelle dans la France du XIXe siècle », Les mythes de la science, inventeurs et invention, Colloque organisé par la MSH-Nord-Pas-de-Calais.

Galvez-Behar, G. (2010) «Controverses et paradoxes dans 1'Europe des brevets au XIXe siècle », Eck, J-F. Tilly, P. Innovations, réglementations et transferts de technologie en Europe du Nord-ouest aux XIXe et XXe siècles, Oct. 2010, Villeneuve d'Ascq, France. Peter Lang, pp.35-51, 2011, Euroclio.

Garnier, J. (1873), Traité d'Economie Politique, Septième Edition, Paris, Guillaumin.

Gharbi, J.S. Sekerler Richiardi, P. (2010) Léon Walras, précurseur du libertarisme de gauche? Halshs-00501838.

Harribey, J-M. (2011), "Le bien commun est une construction sociale. Apports et limites d'Elinor Ostrom.” L'Économie politique, no. 49 (January): 98-112.

Heller, M. Eisenberg, R. (1998), "Can Patents deter Innovation ? The Anticommons in Biomedical research", Science, 1998.

Helprin, M. (2007), “A Great Idea Lives Forever. Shouldn’t Its Copyright?”, The New York Times, 20. 
Hughes, J. (2002), “Fair use across time”, University of California, Los Angeles Law Review, 50,775 .

Hugo, V. (1885), Actes et paroles, Depuis l'exil - 1876 - 1885.

Jobard, J-B Jean-Baptiste (1844), Nouvelle économie sociale ou Monautopole industriel, artistique, commercial et littéraire, fondé sur la pérennité des brevets d'invention, dessins, modèles et marques de fabrique. Paris: chez Mathias.

Jourdain, E. (2017), "Intérêt general, intérêt individual et raison collective: perspectives à partir de l'oeuvre de Proudhon", Astérion, 17, online.

Kitch, E. W. (1977), «The Nature and Function of the Patent System », The Journal of Law \& Economics, Vol. 20, No. 2, pp. 265-290.

Lallement, J. (2011), « La propriété intellectuelle selon Walras : entre monautopole et majorat littéraire », Economia, 1-3, 393-435.

Laval, C. (2016), "“Commun» et "communauté»: un essai de clarification sociologique”, SociologieS [On line], Dossiers, Des communs au commun : un nouvel horizon sociologique ?, uploaded 19/10/2016, last consultation 22/01/2017.

Lemennicier, B. (1995), La propriété des inventions : propriété naturelle ou monopole ?, cycle de conférences-débats mensuelles Les dynamiques libérales de l'histoire économique de la France, huitième conférence, 15 mars 1995.

Leroy, M. (1913), La Coutume ouvrière, Éditions CNT-RP, Paris, 2007.

Lessig, L. (2008), Remix: Making Art and Commerce Thrive in the Hybrid Economy, Penguin Books, 2009.

Liu, D. (2014), "Patent, but where is home and global justice? A rawlsian and senian inquiry", Chicago-Kent journal of intellectual property, vol 14:1.

Liu, J. P. (2002), “Copyright and Time: A Proposal”, Michigan Law Review, 101(2), 409-481.

Malchup, F. Penrose, E. (1950), "The Patent Controversy in the Nineteenth Century", The Journal of Economic History, Vol. 10, No.1, May, pp. 1-59.

Mangolte, P. A. (2010), "Brevets d'invention" de Charles Coquelin (1852), une critique de la propriété des inventions », CEPN-CNRS Université Paris-Nord.

Mauss, M. (1924) Essai sur le don: Forme et raison de l'échange dans les sociétés archaïques, 1973, PUF, Collection Quadrige, 149-279 p.

Merges, R. (2011), Justifying Intellectual Property, Harvard University Press.

Molinari, G. (1852), «Propriété littéraire », Dictionnaire de l'économie politique, Paris : Guillaumin, t II, pp. 473-478. 
Molinari, G. (1855), «De la propriété des inventions », Journal des Economistes, $2^{\text {ème }}$ série, t. $27, \mathrm{n}^{\circ}$ 9, Sep, 410-430.

Molinari, G. (1856), «La propriété des inventions, réplique à M. Frédéric Passy », Journal des Economistes, janvier-mars.

Moore, A. (2001), Intellectual property and information control: philosophic foundations and contemporary issues. Transaction Publishers, 2001.

Moore. A. D. (2001), Intellectual Property and Information Control : Philosophic Foundations and Contemporary Issues, Transaction Publishing, PDF Draft.

Mossoff, A. (2014), Intellectual Property and Property Rights, George Mason Law \& Economics Research Paper No. 14-31.

Ostrom, E. (1990), Governing the Commons: The Evolution of Institutions for Collective Action, New York, Cambridge University Press.

Ostrom, E., Hess, C. (2007), Understanding Knowledge as a Common, 2011, MIT Press.

Passy, F. Modeste, V. Paillottet, P. (1859), De la Propriété Intellectuelle, E. Dentu, Paris.

Pfister, L. (1999), L'auteur, propriétaire de son œuvre ? La formation du droit d'auteur $d u$ XVIe siècle à la loi de 1957, thèse de droit, sous la direction de J.-M. Poughon, Université Strasbourg III.

Poinsot, P. (2014), L'utile est-il juste ou le juste est-il utile ? Les débats entre Jules Dupuit et les libéraux français $d u$ dix-neuvième siècle sur les droits de propriété intellectuelle. IVe Congrès de l'AFEP, Paris, France.

Polanyi, K. (1944), La Grande Transformation, 1983, trad. Malamoud, C. Angeno. M, Gallimard,

Proudhon, P. J. (1840), Qu'est ce que la propriété, Premier Mémoire, 1966, GarnierFlammarion, Paris.

Proudhon, P. J. (1841), Lettre à AM. Blanqui sur la propriété, Secon Mémoire, Librairie De Prévot, Paris.

Proudhon, P. J. (1843), De la Création de l'Ordre dans l'Humanité, 1873, A. Lacroix \& Cie.

Proudhon, P. J. (1846), Système des contradictions économiques, Tome 1, Paris : Guillaumin.

Proudhon, P. J. (1858), De la justice dans la Révolution et dans l'Eglise, Paris, Garnier frères.

Proudhon, P. J. (1862), Les majorats littéraires. Examen d'un projet de loi ayant pour but de créer, au profit des auteurs, inventeurs et artistes, un monopole perpétuel. Paris : E. Dentu, 1863. 
Proudhon, P. J. (1865), Du principe de l'art et de sa destination sociale, A. Lacroix et Cie Editeurs, 1875.

Proudhon, P. J. (1866), Théorie de la Propriété, édité par Tremblay J. M., format PDF.

Proudhon, P. J. (2010), «Un inédit de Pierre-Joseph Proudhon. Après Karl Marx, pourquoi lire un inédit de Pierre-Joseph Proudhon ? », Cités, 3/2010 ( ${ }^{\circ} 43$ ), p. 127-181.

Renouard, A-C. (1838), Traité des droits d'auteurs, dans la littérature, les sciences et les beaux-arts, Paris : Jules Renouard.

Renouard, A-C. (1844), Traité des brevets d'invention, édition entièrement nouvelle, Paris : Guillaumin.

Renouard, A-C. (1860), Du droit industriel dans son rapport avec les principles du droit civil sur les personnes et sur les choses, Paris, Guillaumin.

Rideau, F. (2010), "Nineteenth Century Controversies Relating to the Protection of Artistic Property in France", Privilege and Property edited by Deazley, R. Kretschmer, M. Bently, L., One Book Publishers, Cambridge.

Sagot-Duvauroux D. (2004), «La propriété intellectuelle, c'est le vol ! Le débat sur le droit d'auteur au milieu du XIXe siècle », L'Économie politique, 2 (no 22), p. 34-52.

Sapiro, G. (2014), "Droit et histoire de la littérature: la construction de la notion d'auteur", Revue d'histoire du XIXe siècle, 48 | 2014, 107-122.

Schulman, N. (1990), "Informational Property: Logorights.", Journal of Social and Biological Structures (1990).

Scotchmer, S. (2004), Innovation and incentives, Cambridge, MIT Press.

Sigot. N. (2010), "Utility and Justice: French Liberal Economists in the 19th Century", European Journal of the History of Economic Thought, 17 (4), pp.759-792.

Walras, L. (1859), «De la propriété intellectuelle. Position de la question économique », Journal des économistes, 24(12) : 392-407.

Walras, L. (1880a), « De la propriété intellectuelle », Gazette de Lausanne, 10 juin.

Walras, L. (1880b), « De la propriété intellectuelle », Gazette de Lausanne, 11 juin.

Walras, L. (1880c), « De la propriété intellectuelle », Gazette de Lausanne, 12 juin.

Wolowski, M. L. (1840), Cours de Législation Industrielle, Bureau de la revue de la Législation et de la Jurisprudence, Paris.

Xifaras, M. (2010), « Le copyleft et la théorie de la propriété », Multitudes, 2 (n41), p. 5064.

Zola, E. (1866), Mes Haines : causeries littéraires et artistiques, Paris : A. Faure. 
